\title{
Menggalang Potensi Budaya Lokal untuk Mengangkat Bargaining Position Masyarakat: Memetik Hikmah Pemetaan Partisipatif di Gunungkidul
}

\author{
J. Susetyo Edy Yuwono', Uji Nugroho Winardi² \\ ${ }^{1}$ Departemen Arkeologi, Fakultas Ilmu Budaya, Universitas Gadjah Mada \\ ${ }^{2}$ Departemen Sejarah, Fakultas Ilmu Budaya, Universitas Gadjah Mada
}

\begin{abstract}
The district of Gunungkidul was chosen as a potential area for the adoption of a new approach in Community Engagement (CE) program. Participatory mapping, reinforced by the application of the Geographic Information System (GIS) as a new approach, became a breakthrough amid the vastness of humanities, which still seems to be fragmented in each study program. Therefore, a platform is neended to optimize the potential of FIB UGM to address the diversity of cultural aspects in a community. This $C E$ is designed to empower both parties at once, ie community and college. For the community, recollecting of their cultural properties can be a powerful capital for potential development with a structured and accessible database. This cultural richness helps them to initiate and implement the sustainable village development programs. Strengthening and developing their identity and integrity of local culture can be achieved if their overall potential can be mapped. For the college, CE becomes a model that can provide more mature readiness in actualizing its "tri dharma", either through the preparation of human resources and methodological reinforcement.
\end{abstract}

Keywords: Community engagement, GIS, Participatory mapping.

\begin{abstract}
Abstrak
Kabupaten Gunungkidul dipilih sebagai wilayah yang berpotensi bagi penerapan pendekatan baru di dalam program Pengabdian kepada Masyarakat (PPM). Pemetaan partisipatif yang diperkuat dengan penerapan Geographic Information System (GIS) sebagai pendekatan baru, dijadikan terobosan di tengah-tengah luasnya ranah humaniora, yang masih terkesan terkotakkotak di masing-masing program studi (prodi). Oleh karena itu, diperlukan wahana untuk mengoptimalkan potensi FIB UGM dalam skema fakultas (lintas prodi) untuk menyikapi keberagaman aspek budaya di masyarakat. PPM ini dirancang untuk memberdayakan kedua belah pihak sekaligus, yaitu masyarakat dan perguruan tinggi. Bagi masyarakat, penggalangan kembali kekayaan budaya mereka menjadi modal kuat bagi pengembangan potensi ke depan dengan basisdata yang terstruktur dan mudah diakses. Kekayaaan budaya tersebut sangat membantu mereka untuk menggagas dan melaksanakan program pengembangan desa secara berkesinambungan. Penguatan dan pengembangan identitas dan integritas budaya lokal dapat dicapai jika keseluruhan potensi yang mereka miliki dapat dipetakan. Bagi perguruan tinggi, PPM ini menjadi model yang dapat memberikan kesiapan lebih matang dalam mengaktualisasikan "tri dharma"nya, baik melalui penyiapan sumberdaya manusia maupun penguatan metodologinya.
\end{abstract}

Kata kunci: Pengabdian kepada Masyarakat, GIS, Pemetaan partisipatif. 


\section{Pendahuluan}

Sebuah terobosan baru sudah digulirkan oleh tim PPM Fakultas Ilmu Budaya Universitas Gadjah Mada (FIB UGM) di Kecamatan Wonosari, Kabupaten Gunungkidul, Daerah Istimewa Yogyakarta tahun 2017 (Yuwono dkk., 2017). Terobosan yang dimaksud berupa sebuah format pemetaan partisipatif terhadap potensi budaya lokal sebagai model untuk mengaktualisasikan kontribusi perguruan tinggi dalam membantu menguatkan dan mengembangan identitas dan integritas budaya masyarakat di lokasi sasaran.

Tiga butir penting yang menjadi tekanan dari PPM ini adalah:

- Terjalinnya kolaborasi sebagian besar program studi (prodi) yang ada di FIB UGM. Dalam realisasi PPM ini keunikan masing-masing prodi tetap menonjol tetapi dapat dikolaborasikan dalam satu kesatuan misi dan metode. Dasar asumsinya adalah, fenomena budaya yang berlangsung di masyarakat tidak pernah terkotakkotak layaknya representasi prodi-prodi di perguruan tinggi. Namun tidak dapat dipungkiri bahwa masterpiece unsur-unsur budaya yang menonjol di masing-masing komunitas/desa boleh jadi sesuai dengan kompetensi prodi tertentu.

- Penulis beranggapan bahwa pemetaan partisipatif yang sudah dilaksanakan di Gunungkidul membuktikan bahwa penerapan teknologi perpetaan berbasis Geographic Information System (GIS) bukan hal yang mustahil bagi ilmu-ilmu humaniora di Indonesia, khususnya di FIB UGM. Satu gebrakan teknologi yang di "luar" sana, sudah dikembangkan sedemikian majunya oleh para sejarawan dan ahli-ahli ilmu humaniora lainnya, sementara di FIB UGM teknologi tersebut belum tersentuh.

- PPM adalah kegiatan yang keberhasilan atau kegagalannya tidak seketika dapat diukur usai pelaksanaan di lapangan. Kenyataan bahwa hingga hari ini - empat bulan setelah kegiatan berakhir -- masih ada beberapa desa yang mengirimkan pembaharuan data kepada penulis, sungguh dapat dijadikan tolok ukur seberapa jauh masyarakat Wonosati merespon dan menaruh harapan atas PPM ini.

Tiga butir di atas diangkat sebagai sorotan utama dalam artikel ini. Sebuah bentuk pelaporan, kontemplasi, dan sekaligus harapan ke depan atas apa yang sudah dimulai oleh penulis bersama tim pada 2017.

\section{Langkah-Langkah Kolaboratif}

Tercatat enam prodi yang terlibat dan berkolaborasi dalam PPM berjudul Pemetaan Partisipatif Potensi Budaya Gunungkidul untuk Penguatan dan Pengembangan Identitas dan Integritas Budaya Lokal (Tahap I: Kecamatan Wonosari) ini. Keenamnya adalah Antropologi, Arkeologi, Sejarah, Pariwisata, Bahasa Indonesia, dan Sastra Jawa. Lima prodi bahasa asing yang ada di FIB UGM sementara belum dilibatkan. Bukannya tidak ada peluang, tetapi rintisan PPM skema fakultas ini memang sedang membangun sebuah model. Model PPM yang diupayakan berbeda dengan rutinitas PPM yang selama ini terkesan (meminjam istilah Dr. Agus Suwignyo, M.A.) sekedar "menggugurkan kewajiban".

Menurut apa yang penulis rasakan dan alami, "keasyikan dan totalitas" dari PPM ini terletak pada masing-masing tahap di bawah ini: 


\section{Tahap persiapan}

Terdapat enam kegiatan dalam tahap persiapan yang perlu dilaporkan, yaitu:

- Perumusan entitas budaya/tema yang akan dipetakan beserta kandungan informasi/ atributnya (Tabel 1).

- Perancangan format basisdata tabular (Tabel 2).

- Penyiapan form isian untuk input data mengacu pada rancangan basisdata.

- Penyiapan peta dasar (RBI) digital, citra satelit, dan perangkat lunak (Quantum GIS dan GoogleEarth), serta pembuatan template/project.

- Penyiapan materi presentasi untuk pengenalan masing-masing prodi.

- Workshop dan simulasi input data ke dalam prosedur dan cara kerja GIS. Kegiatan ini diperuntukkan bagi internal tim yang berjumlah 12 orang (tiga dosen dan sembilan mahasiswa) (Foto 1).

- Perijinan, penyiapan lokasi, penyiapan akomodasi dan transportasi, penyiapan administrasi, serta penyiapan peserta/masyarakat.

Tabel 1. Pengelompokan data berdasarkan tema dan subtema

\begin{tabular}{|c|c|}
\hline TEMA & SUBTEMA \\
\hline \multirow{6}{*}{$\begin{array}{l}\text { Bangunan/ } \\
\text { Struktur }\end{array}$} & Jalan \\
\hline & Pondok Pesantren \\
\hline & Rumah Sakit \\
\hline & Rumah Tradisional \\
\hline & $\begin{array}{l}\text { Rumah/Gedung } \\
\text { Bersejarah }\end{array}$ \\
\hline & Tugu \\
\hline \multirow{12}{*}{$\begin{array}{l}\text { Industri dan } \\
\text { Kerajinan }\end{array}$} & Bambu \\
\hline & Batik \\
\hline & Batu \\
\hline & Besi \\
\hline & Gamelan \\
\hline & Kayu \\
\hline & Pendhok \\
\hline & Perak \\
\hline & Sangkar Burung \\
\hline & Serat \\
\hline & Tembaga \\
\hline & Wayang \\
\hline $\begin{array}{l}\text { Kelompok/ } \\
\text { Komunitas }\end{array}$ & $\begin{array}{l}\text { Rumah Budaya/Home } \\
\text { Stay }\end{array}$ \\
\hline
\end{tabular}

\begin{tabular}{|c|c|}
\hline Kepercayaan & Pransuh \\
\hline \multirow{19}{*}{ Kesenian } & Bergada \\
\hline & Campursari \\
\hline & Gejog Lesung \\
\hline & Hadrah \\
\hline & Jathilan \\
\hline & Karawitan \\
\hline & Keroncong \\
\hline & Kethoprak \\
\hline & Ledhek \\
\hline & Macapat \\
\hline & Pedalangan \\
\hline & Rebana \\
\hline & Reog \\
\hline & Sanggar Seni \\
\hline & Sholawatan \\
\hline & Tari \\
\hline & Tayuban \\
\hline & Thoklik \\
\hline & Wayang \\
\hline
\end{tabular}




\begin{tabular}{|c|l|}
\hline $\begin{array}{c}\text { Kuliner } \\
\text { Tradisional }\end{array}$ & Kuliner Tradisional \\
\hline Megalitik & Megalitik \\
\hline \multirow{4}{*}{ Objek Alam } & Goa \\
\cline { 2 - 2 } & Gunung \\
\cline { 2 - 2 } & Hutan \\
\cline { 2 - 2 } & Suata Air \\
\cline { 2 - 2 } & Telaga \\
\hline \multirow{4}{*}{ Pemakaman } & Makam Kolonial \\
\cline { 2 - 2 } & Makam Pahlawan \\
\cline { 2 - 2 } & Makam Tionghoa \\
\cline { 2 - 2 } & Makam Tokoh \\
\hline \multirow{2}{*}{$\begin{array}{c}\text { Pengobatan } \\
\text { Tradisional }\end{array}$} & Jamu \\
\cline { 2 - 2 } & Pijat \\
\hline \multirow{5}{*}{ Perdukunan } & Dukun Bayi \\
\cline { 2 - 2 } & Paranormal \\
\cline { 2 - 2 } & Pranoto Mongso \\
\cline { 2 - 2 } & Siklus Hidup \\
\hline \multirow{2}{*}{ Perekonomian } & Pasar \\
\cline { 2 - 2 } & Pegadaian \\
\hline
\end{tabular}

\begin{tabular}{|c|l|}
\hline \multirow{4}{*}{$\begin{array}{c}\text { Peribadatan dan } \\
\text { Pemujaan }\end{array}$} & Candi \\
\cline { 2 - 2 } & Gereja \\
\cline { 2 - 2 } $\begin{array}{c}\text { Permainan } \\
\text { Tradisional }\end{array}$ & Masjid \\
\cline { 2 - 2 } $\begin{array}{c}\text { Petilasan/Cerita } \\
\text { Rakyat }\end{array}$ & Jemparangan \\
\hline \multirow{5}{*}{ Retilasan/Cerita } \\
\hline \multirow{5}{*}{ Upacara Adat }
\end{tabular}

Penentuan tema dan subtema di atas menjadi sebuah proses tersendiri yang memerlukan diskusi intensif dari enam prodi yang terlibat. Penyatuan metodologi antar bidang ilmu untuk merancang sebuah proyek bersama seperti ini kenyataannya tidak mudah dilakukan. Selain persoalan metodologis, sisi lain dari pekerjaan kolaboratif yang harus dirumuskan pada tahap persiapan terletak pada persoalan teknik dan prosedur pemetaan digital. Upaya ini menuntut ketepatan dan keseragaman dalam hal format data dan aturan-aturan kartografis yang dapat mengkompilasikan entitas berbagai prodi yang berbeda karakter. Kegiatan workshop dan simulasi input data bagi semua anggota tim merupakan langkah persiapan untuk menjembatani kesenjangan pengetahuan dan keterampilan dalam melaksanakan pemetaan nantinya (Foto 1). 


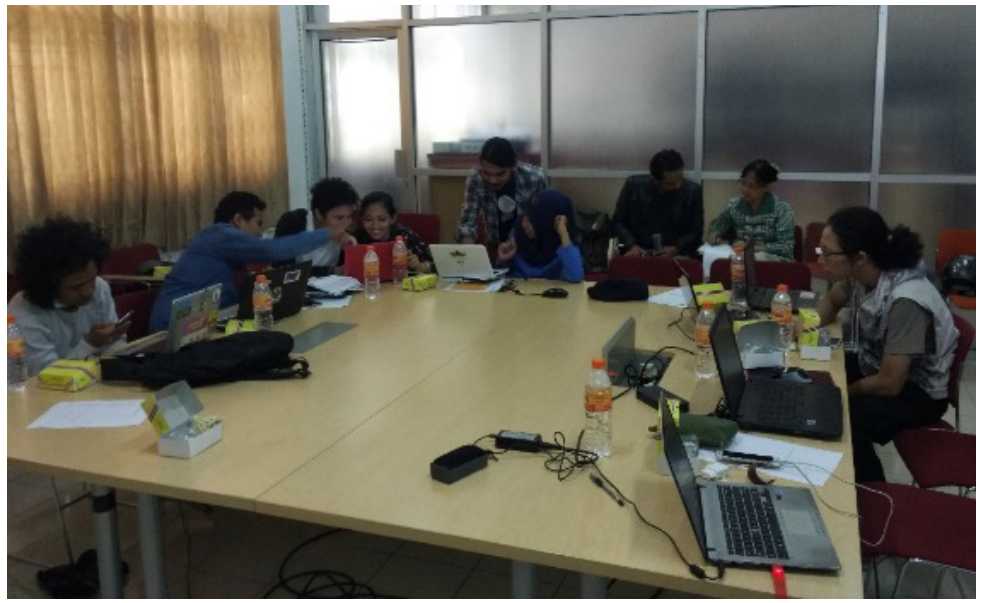

Foto 1. Workshop dan simulasi input data di FIB UGM (dok. Tim PPM GK 2017)

Tabel 2. Struktur basisdata budaya Kabupaten Gunungkidul

\begin{tabular}{|c|c|c|c|c|c|c|c|c|c|c|}
\hline Id 4 & Name & Edit widget & Alias & Type & Type name & Length & Precision & Comment & WMS & WFS \\
\hline 1230 & ID & Text Edit & & qlonglong & Integer64 & 10 & 0 & & $\checkmark$ & $\checkmark$ \\
\hline abc 1 & NO & Text Edit & & QString & String & 10 & 0 & & $\checkmark$ & $\checkmark$ \\
\hline abc 2 & NAMA & Text Edit & & QString & String & 100 & 0 & & $\checkmark$ & $\checkmark$ \\
\hline abc 3 & ID_TEMA & Text Edit & & QString & String & 10 & 0 & & $\checkmark$ & $\checkmark$ \\
\hline abc 4 & TEMA & Text Edit & & QString & String & 50 & 0 & & $\checkmark$ & $\nabla$ \\
\hline abc 5 & ID_SUBTEMA & Text Edit & & QString & String & 10 & 0 & & $\checkmark$ & $\checkmark$ \\
\hline abc 6 & SUBTEMA & Text Edit & & QString & String & 50 & 0 & & $\checkmark$ & $\checkmark$ \\
\hline abc 7 & BENTUK & Text Edit & & QString & String & 30 & 0 & & $\checkmark$ & $\checkmark$ \\
\hline 1238 & ARKEO & Text Edit & & qlonglong & Integer64 & 10 & 0 & & $\checkmark$ & $\nabla$ \\
\hline و 123 & ANTRO & Text Edit & & qlonglong & Integer64 & 10 & 0 & & $\checkmark$ & $\checkmark$ \\
\hline $123 \quad 10$ & SEJARAH & Text Edit & & qlonglong & Integer64 & 10 & 0 & & $\checkmark$ & $\checkmark$ \\
\hline 12311 & PARIWISATA & Text Edit & & qlonglong & Integer64 & 10 & 0 & & $\checkmark$ & $\nabla$ \\
\hline 12312 & BHS_SASTRA & Text Edit & & qlonglong & Integer 64 & 10 & 0 & & $\nabla$ & $\nabla$ \\
\hline abc 13 & DUSUN & Text Edit & & QString & String & 50 & 0 & & $\checkmark$ & $\nabla$ \\
\hline abc 14 & DESA_KEL & Text Edit & & QString & String & 50 & 0 & & $\checkmark$ & $\checkmark$ \\
\hline abc 15 & KECAMATAN & Text Edit & & QString & String & 50 & 0 & & $\checkmark$ & $\checkmark$ \\
\hline abc 16 & KAB_KOTA & Text Edit & & QString & String & 50 & 0 & & $\nabla$ & $\nabla$ \\
\hline abc 17 & PROVINSI & Text Edit & & QString & String & 50 & 0 & & $\checkmark$ & $\nabla$ \\
\hline abc 18 & ZONA_UTM & Text Edit & & QString & String & 10 & 0 & & $\checkmark$ & $\checkmark$ \\
\hline 12319 & $x$ & Text Edit & & qlonglong & Integer 64 & 10 & 0 & & $\checkmark$ & $\checkmark$ \\
\hline 12320 & $Y$ & Text Edit & & qlonglong & Integer64 & 10 & 0 & & $\checkmark$ & $\nabla$ \\
\hline 1.221 & BUJUR & Text Edit & & double & Real & 14 & 6 & & $\checkmark$ & $\nabla$ \\
\hline $1.2 \quad 22$ & LINTANG & Text Edit & & double & Real & 14 & 6 & & $\checkmark$ & $\checkmark$ \\
\hline abc 23 & UPDATE & Text Edit & & QString & String & 50 & 0 & & $\checkmark$ & $\checkmark$ \\
\hline
\end{tabular}




\section{Tahap kegiatan lapangan}

Dua kegiatan pokok dalam tahap pelaksanaan berupa kunjungan lapangan dan input data melalui focus group discussion (FGD) pada tanggal 28-29 Agustus 2017. Kunjungan lapangan dilakukan di Desa Mulo dan Desa Gari sebagai lokasi simulasi input data (Foto 2 dan 3). Bersamaan dengan itu dilakukan pula pengamatan ke beberapa situs (Foto 4) dan ritual tradisi (Foto 5).

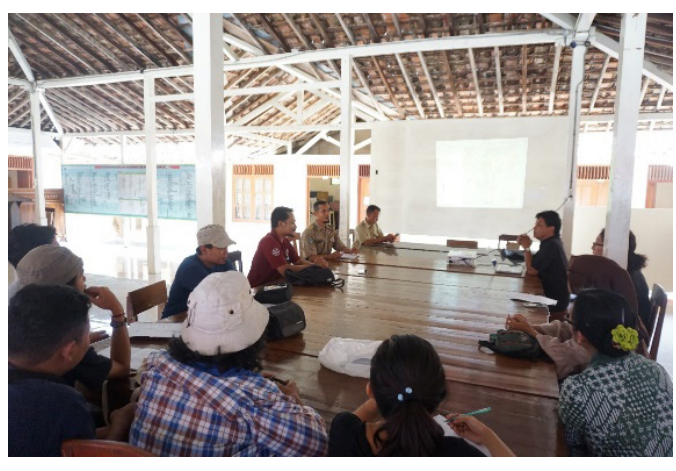

Foto 2. Simulasi input data ke peta digital di Desa Mulo (dok. Tim PPM GK 2017)

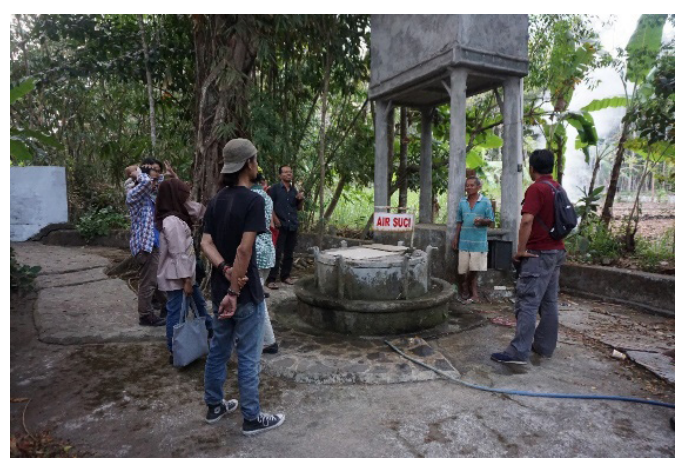

Foto 4. Kunjungan situs di Desa Gari (dok. Tim PPM GK 2017)

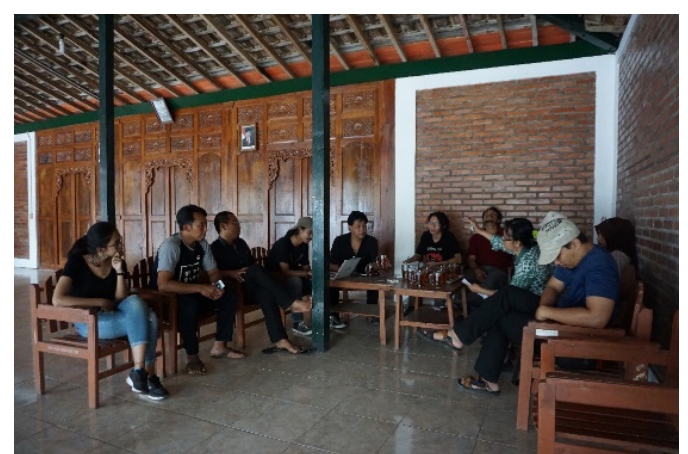

Foto 3. Simulasi input data ke peta digital di Desa Gari (dok. Tim PPM GK 2017)

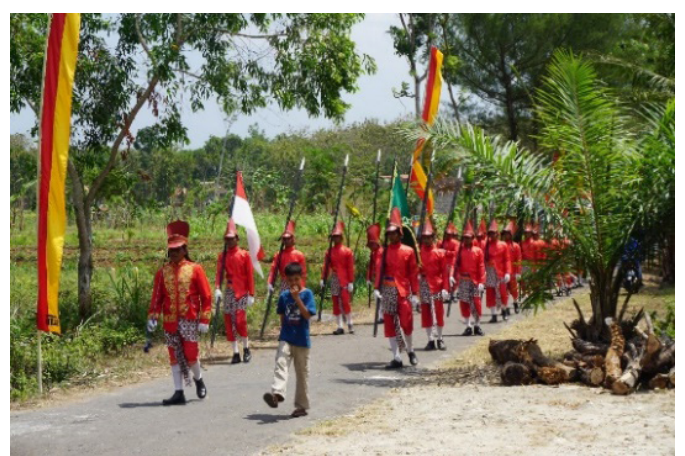

Foto 5. Pengamatan tradisi rasulan di Desa Karangrejek (dok. Tim PPM GK 2017)

Kegiatan FGD untuk input data budaya dilaksanakan di kantor Kecamatan Wonosari, dihadiri wakil dari 14 desa se Kecamatan Wonosari, beberapa dinas terkait, dan beberapa tokoh budaya Gunungkidul. Sejumlah 429 entitas budaya di Kecamatan Wonosari berhasil dipetakan dan disusun dalam basisdata digital. Selain para informan dari masing-masing desa dan kantor dinas, proses pemetaan partisipatif juga melibatkan tiga dosen sebagai pengarah dan narasumber, serta sembilan mahasiswa sebagai operator dan fasilitator. Prosedur pemetaan partisipatif dan form isian data tersaji di bawah ini. 


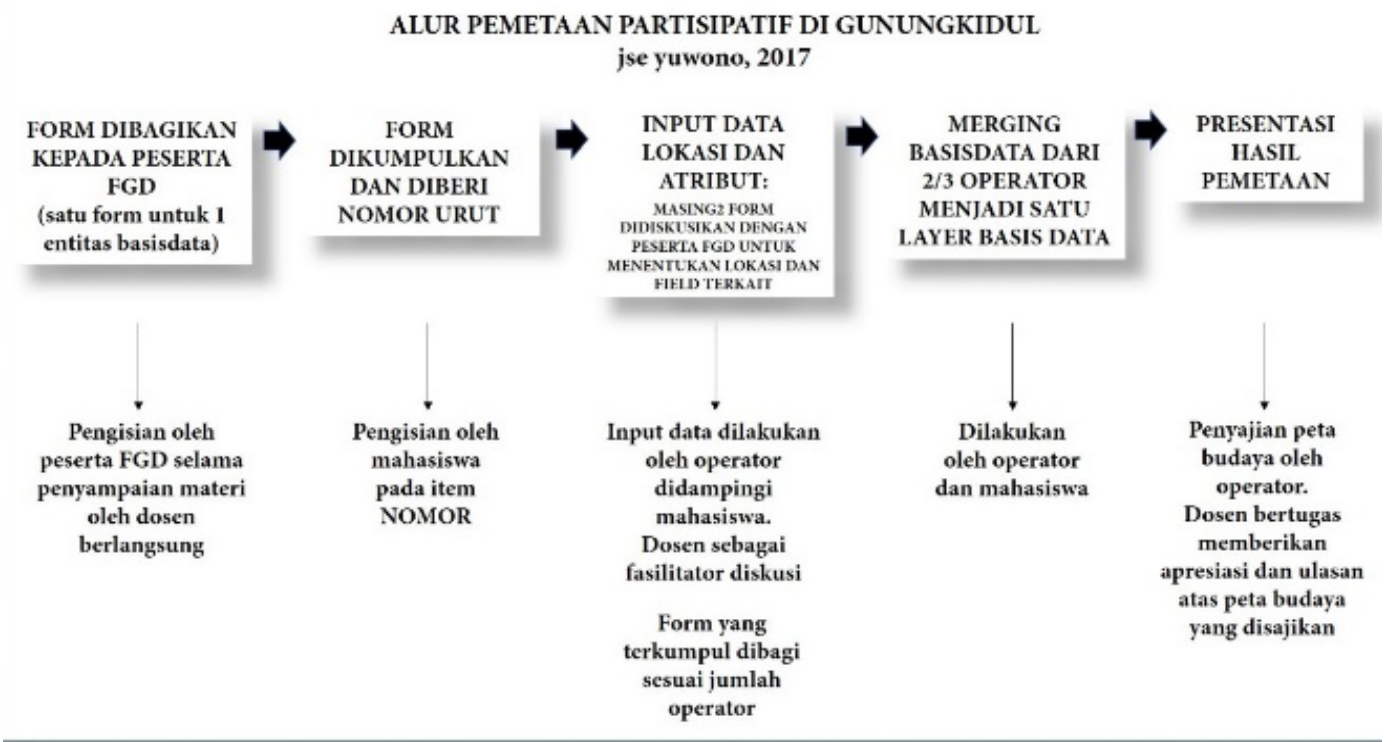

FORM ISLAN DATA BUDAYA GUNUNGKIDUL 2017

No Objek:

\begin{tabular}{|l|}
\hline Nama Narasumber : \\
\hline Tanggal Input : \\
\hline
\end{tabular}

\begin{tabular}{|ll|}
\hline 1. & Nama Objek : \\
\hline 2. & Dusun \\
\hline 3. & Desa/Kelurahan : \\
\hline 4. & Kecamatan: \\
\hline 5. & Kabupaten/Kota : \\
\hline 6. & Provinsi \\
\hline
\end{tabular}

\begin{tabular}{|ll|}
\hline 1. D_Tema & $:$ \\
\hline 2. Tema & $:$ \\
\hline 3. D_Subtema & $:$ \\
\hline 4. Subtema & $:$ \\
\hline 5. Potensi Kajian & $: \square$ Arkeologi $\square$ Antropologi $\square$ Sastra $\square$ Sejarah $\square$ Pariwisata \\
\hline 6. Update Data & $:$ \\
\hline 7. Bujur & $:$ \\
\hline 8. Lintang & $:$ \\
\hline 9. Zona UTM & $:$ \\
\hline 10. X & $:$ \\
\hline 11. Y & $:$ \\
\hline 12. Link_PDF : \\
\hline 13. Link_Video \\
\hline
\end{tabular}


Gambaran umum perolehan data hasil pemetaan partisipatif di Kecamatan Wonosari, Kabupaten Gunungkidul dapat dilihat pada diagram 1, 2, dan 3. Diagram 1 menyajikan perbandingan jumlah entitas budaya antar desa; diagram 2 berisi lima tema utama yang paling dominan di Kecamatan Wonosari; dan diagram 3 menyajikan perbandingan jumlah entitas budaya menurut kompetensi prodi di FIB UGM.
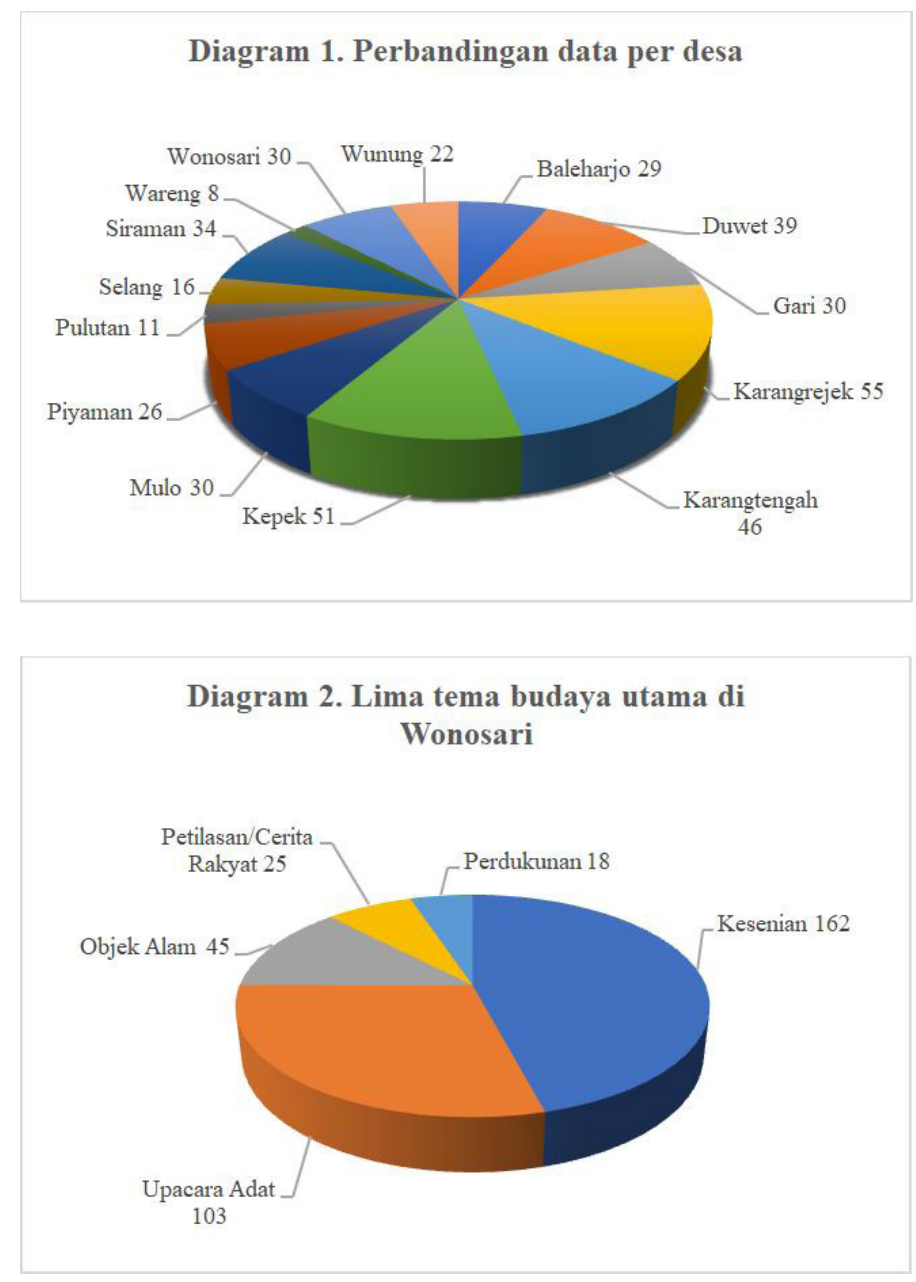

Diagram 3. Perbandingan data per potensi

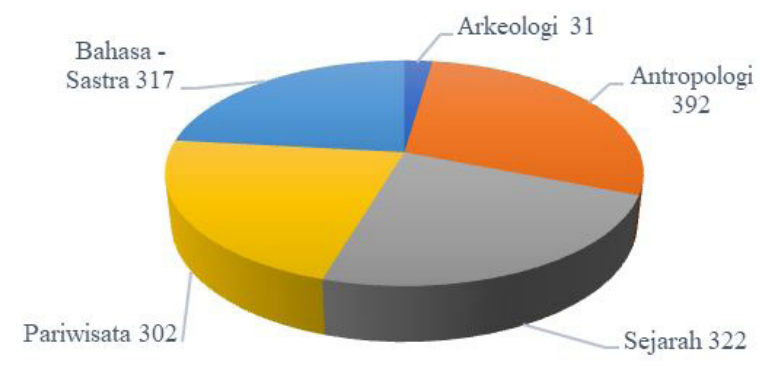




\section{Tahap Pasca Lapangan}

Tahapan ini merupakan tahapan terpanjang dan sekaligus "ujian” bagi keberhasilan kolaborasi, baik di antara sesama anggota tim (enam prodi) maupun antara tim dengan masyarakat. Empat kegiatan yang tercakup di dalam tahap ini berupa: a) pengolahan dan sinkronisasi data antara form isian, catatan lapangan, dan basis data tabular, b) updating dan editing data dengan terus-menerus menjalin komunikasi dengan beberapa aparat desa, c) pengolahan statistik dan pembuatan peta budaya, d) penyerahan peta hasil dan basisdata budaya ke kantor kecamatan dan masing-masing desa.

Kegiatan terakhir (d) sekaligus merupakan bentuk hilirisasi dari pelaksaan PPM. Umpan balik dari para aparat desa dan kecamatan setelah menerima hasil PPM cukup bervariasi. Sebagian sangat melegakan, namun sebagian lainnya justru mengisyaratkan bahwa kegiatan PPM baru akan dimulai. Empat ratus lebih entitas budaya yang sudah terkumpul seolah-olah baru pancingan untuk menggali lebih banyak lagi. Penulis menyadari hal ini justru setelah melalui komunikasi pribadi dengan para aparat. Kenyataannya masih banyak data yang pada saat FGD belum diinformasikan oleh perwakilan beberapa desa. Pergeseran lokasi juga terjadi pada beberapa entitas yang sudah dipetakan.

Dengan digunakannya GIS pemutakhiran data secara dinamis ternyata mudah ditangani. Bukan hanya dalam proses editing, GIS juga sangat powerfull untuk menangani volume data yang sangat besar, berasal dari multi-sumber, memiliki dimensi multi-skala, serta representasi yang bersifat multi-tipe (Leung, 2010: 4-5, dalam Yuwono, 2015).

\section{GIS: Akademisi dan Masyarakat}

Dalam Seri Panduan Pemetaan Partisipatif (Hidayat dkk., 2005), langkah-langkah pemetaan partisipatif dimulai dari pemahaman akan tujuan dilakukannya pemetaan hingga penyusunan rencana lanjutan berdasarkan hasil pemetaan (Diagram 4). Secara umum, tahapan PPM ini sesuai dengan panduan yang dimaksud. Identik dengan prosedur tersebut adalah tahapan di dalam pengoperasian GIS yang mencakup penyusunan conceptual design, operational design, dan cartographic design (Yuwono, 2015).

\section{Diagram 4}

\begin{tabular}{|c|}
\hline (1) Memahami pemetaan partisipatif \\
\hline (2) Memperkenalkan ide pemetaan \\
\hline (3) Kesepakatan-kesepakatan masyarakat \\
\hline (4) Perencanaan kegiatan pemetaan \\
\hline (5) Pelatihan teknik pemetaan \\
\hline (6) Memetakan pengetahuan lokal/Survei pemetaan \\
\hline \\
(7) Menggambar peta \\
\hline $\begin{array}{c}\text { (8) Memeriksa peta, pengesahan peta } \\
\text { dan penyusunan rencana lebih lanjut }\end{array}$ \\
\hline
\end{tabular}


Desain konseptual berupa ragam tema - subtema dan struktur basisdata merupakan upaya integratif baik secara internal (substansi antar prodi) maupun eksternal (FIB UGM dengan masyarakat sasaran). Hal ini sejalan dengan butir (1) hingga (4) pada diagram 3. Desain operasional diwujudkan dalam form isian data dan alur pelaksanaan PPM yang tidak dapat dilaksanakan tanpa kerja sama nyata dengan masyarakat. Butir (5) dan (6) pada diagram 3 memberikan ilustrasi yang jelas mengenai desain operasional. Desain kartografis diwujudkan melalui peta hasil berbasis digital yang bersifat tematik, tanpa mengesampingkan kaidah-kaidah kartografis. Hal ini kira-kira sejalan dengan butir (7) dan (8) pada diagram 3. Persoalan peta dasar, datum, dan sistem koordinat tetap menjadi prasyarat penting untuk dapat mewadai fenomena budaya di masyarakat ke dalam peta-peta tematik.

Berdasarkan ketiga rancangan di atas, maka pengaplikasian GIS dalam PPM ini dapat menjadi jembatan antara akademisi dengan masyarakat. Mulai tahap persiapan hingga pasca lapangan, model PPM yang dilaksanakan sangat membutuhkan GIS, baik sebagai alat maupun cara kerja.

"GIS can be narrowly viewed as just a tool, but should be viewed more broadly as an approach or way of working" (Brimicombe 2010: 44).

\section{Paradigma Pengabdian kepada Masyarakat dalam Kegiatan Pemetaan Partisipatif}

Tiga atau dua dasawarsa yang lampau, banyak warga Gunungkidul - yang secara almiah merupakan wilayah tandus - merantau untuk memperoleh peluang ekonomi yang lebih baik. Tidak dapat dipungkiri "uang rantau" kala itu sangat diandalkan sebagai sumber penghidupan yang utama. Ketika zaman berubah, Gunungkidul saat ini panen berkah dari sektor pariwisata. Potensi alam dan beragam potensi wisata dapat menjadi sumber ekonomi baru yang membawa kesejahteraan dalam skala yang luas.

Permasalahannya, seberapa optimalkah potensi ini telah dapat termanfaatkan? seberapa terencana? dan sejauh mana keberlanjutan dari pemanfaatan potensi masyarakat tersebut telah diprogramkan?

Dalam berbagai kasus, potensi yang ada dapat sewaktu-waktu berubah dari berkah menjadi musibah. Formulasi kebijakan yang tidak didukung perencanaan yang matang, justru dapat meredupkan potensi yang ada. Kasus spesifik yang telah lumrah terjadi, sekedar sebagai ilustrasi, adalah adanya persaingan antar pengelola objek wisata karena berebut pasar yang sama. Hal ini disebabkan oleh kurangnya pengetahuan akan potensi yang dimiliki sehingga gagal menciptakan variasi yang mendorong kreativitas pengembangan.

Untuk itu, diperlukan rancangan sistematis agar potensi yang ada dalam masyarakat dapat dimanfaatkan secara optimal. Oleh karenanya, PPM ini didesain guna memfasilitasi masyarakat - melalui institusi pemerintah di tingkat kecamatan dan desa - untuk mengidentifikasi-memetakan, menjaga hingga memanfaatkan potensi budaya yang ada secara optimal. Kekhawatiran akan berubahnya berkah menjadi musibah dapat ditekan jika masyarakat sadar sepenuhnya akan seluruh potensi yang dimilikinya. Bukan secara parsial, tetapi secara utuh. Untuk itu, masyarakat perlu dilibatkan di dalam mengenali 
dan memetakan seluruh potensi mereka sendiri. Kesiapan akan pemanfaatannya pun dapat dirancang sejak awal. Bukan hanya untuk meningkatkan kesejahteraan hidup, tetapi ke depan dapat menjadikannya sebagai penguatan identitas dan integritas budaya lokal. Sebuah aset yang tidak ternilai harganya.

Secara umum, PPM dapat diterjemahkan sebagai kegiatan hilirisasi pegetahuan dari ranah unversitas kepada masyarakat. Dalam prakteknya "pengabdian" dapat diterjemahkan ke dalam tiga bentuk, yakni: pertama, memberi atau filantropi; kedua menyadarkan dan memberdayakan (empowering), dan ketiga menggerakkan dan menghubungkan elemen-elemen potensi dalam masyarakat. Pemetaan Partisipatif ini merupakan usaha untuk menggabungkan prinsip kedua dan ketiga. Berkaitan dengan hal tersebut maka peran PPM ini dapat dirinci sebagai berikut:

- Menstimulasi kesadaran masyarakat di Kecamatan Wonosari akan potensi budaya yang dimilikinya, dan bergerak bersama masyarakat mengidentifikasi dan memetakan potensi tersebut sehingga dapat diberdayakan secara optimal untuk kemaslahatan yang luas.

- Menjejaring atau menghubungkan masyarakat dengan para pihak-pihak yang dapat bersinergi untuk mengoptimalkan potensi yang dimiliki masyarakat Wonosari.

Secara garis besar masyarakat dalam konteks PPM ini dapat dikelompokkan menjadi dua, yakni: a) populasi orang yang mendiami suatu unit geografis tertentu (desa, kecamatan dsb), b) komunitas seperti nelayan, buruh, seniman dll, dengan memberi prioritas pada masyarakat kategori 3T (tertinggal, terluar, dan terpinggirkan) untuk berbagai aspek semisal ekonomi, politik, sosial, budaya dan pengetahuan. Program PPM ini memiliki sasaran secara luas yakni masyarakat Wonosari, yang dalam pelaksanaanya direpresentasikan melalui institusi pemerintahan di tingkat kecamatan dan desa. Dengan mempertimbangkan kriteria tersebut, PPM ini menjadi sangat relevan untuk dilaksanakan di Kecamatan Wonosari Gunungkidul karena sejumlah alasan:

Masyarakat Wonosari dapat masuk dalam kriteria "terluar" dalam konteks akses terhadap sumber-sumber ekonomi dari wisata. Berbeda dengan kecamatan lain yang memiliki objek wisata andalan berupa potensi alam, Wonosari tidak memilikinya, namun wilayah ini sangat maju dalam hal infrastruktur. Oleh karenanya dibutuhkan pemetaan atas potensi lain yang dapat berupa sejarah, kuliner, kriya, dan fasilitas wisata (hotel/penginapan).

Masyarakat Wonosari dapat masuk dalam kriteria "tertinggal” dan "terpinggirkan" secara kebudayaan dan pengetahuan. Meraka dengan mudah mengadopsi beragam produk budaya baru dan cenderung abai terhadap pontensi budaya yang mereka miliki. Hal ini terkait dengan ketertinggalan di bidang pengetahuan di mana terjadi pelambatan produksi pengetahuan masyarakat akan potensi budayanya. Masyarakat belum mengetahui kekayaan yang mereka miliki.

Sejauh ini belum pernah ada usaha serius untuk memetakan potensi budaya di Wonosari dan mempergunakannya sebagai kekuatan yang dapat memberi maslahat secara luas. Konsekuensinya, selain banyak potensi yang tak teridentifikasi juga semakin banyak potensi yang hilang terutama yang bersifat intangible.

Masyarakat perlu memperoleh fasilitasi untuk mengidentifikasi potensi budayanya dan menjejaring dengan parapihak yang dapat membantu mengoptimalkan potensi 
budaya yang ada. Hasil PPM yang berupa peta dan basisdata potensi budaya, diharapkan dapat menjadi alat yang menunjukkan potensi sekaligus kebutuhan aktual masyarakat Wonosari.

Pemeraan partisipatif ini juga melihat bahwa, institusi pemerintah dapat menjadi generator yang menggerakkan dan menghubungkan berbagai elemen potensi di masyarakat dalam bentuk kebijakan. Dengan demikian, program PPM perlu juga berorientasi pada kebijakan (policy planning), dan program dapat diarahkan pada berbagai level pengendali kebijakan. Pada era desentralisasi seperti saat ini, peran pembuat kebijakan di tingkat kabupaten, kecamatan, dan desa menjadi semakin pivotal. Sebagai contoh, desa-desa di Kecamatan Wonosari mengelola dana yang cukup besar namun dalam berbagai kasus terdapat persoalan di mana pembuat kebijakan tidak memiliki agenda yang mapan, sehingga program yang dilaksanakan cenderung kurang menggigit dan berjalan "seperti lumrahnya" (business as usual). Akar masalah ini, salah satunya, muncul karena kurangnya pengetahuan atas potensi dalam masyarakat dan kesempatan yang tersedia. Oleh karenanya, PPM diarahkan untuk mengoptimalkan potensi masyarakat melalui fasilitasi berupa pemetaan potensi budaya yang diharapkan menjadi sarana penguatan dan pengembangan identitas dan integritas budaya lokal.

\section{Hasil Kegiatan}

Kegiatan PPM melalui pemetaan partisipatif di Kecamatan Wonosari, Kabupaten Gunungkidul menghasilkan basisdata dan peta budaya yang dapat dirinci sebagai berikut:

- 429 entitas dari 14 desa (in progress) (diagram 1)

- 78 subtema yang dikelompokkan ke dalam 16 tema budaya (diagram 2)

- Album peta (format A1) berisi 20 peta tematik tingkat desa dan kecamatan (peta 1, 2, dan 3 sebagai contoh).

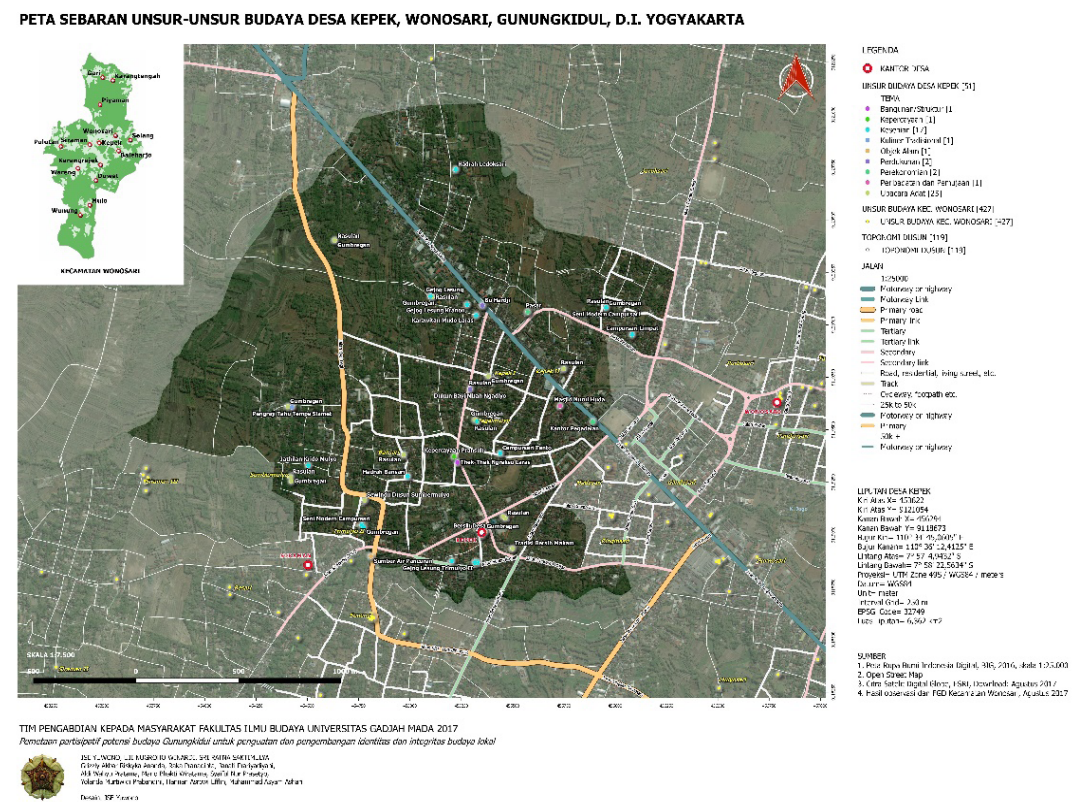

Peta 1. Contoh pemaparan sebaran seluruh tema budaya di Desa Kepek (Layout cetak: A1) 


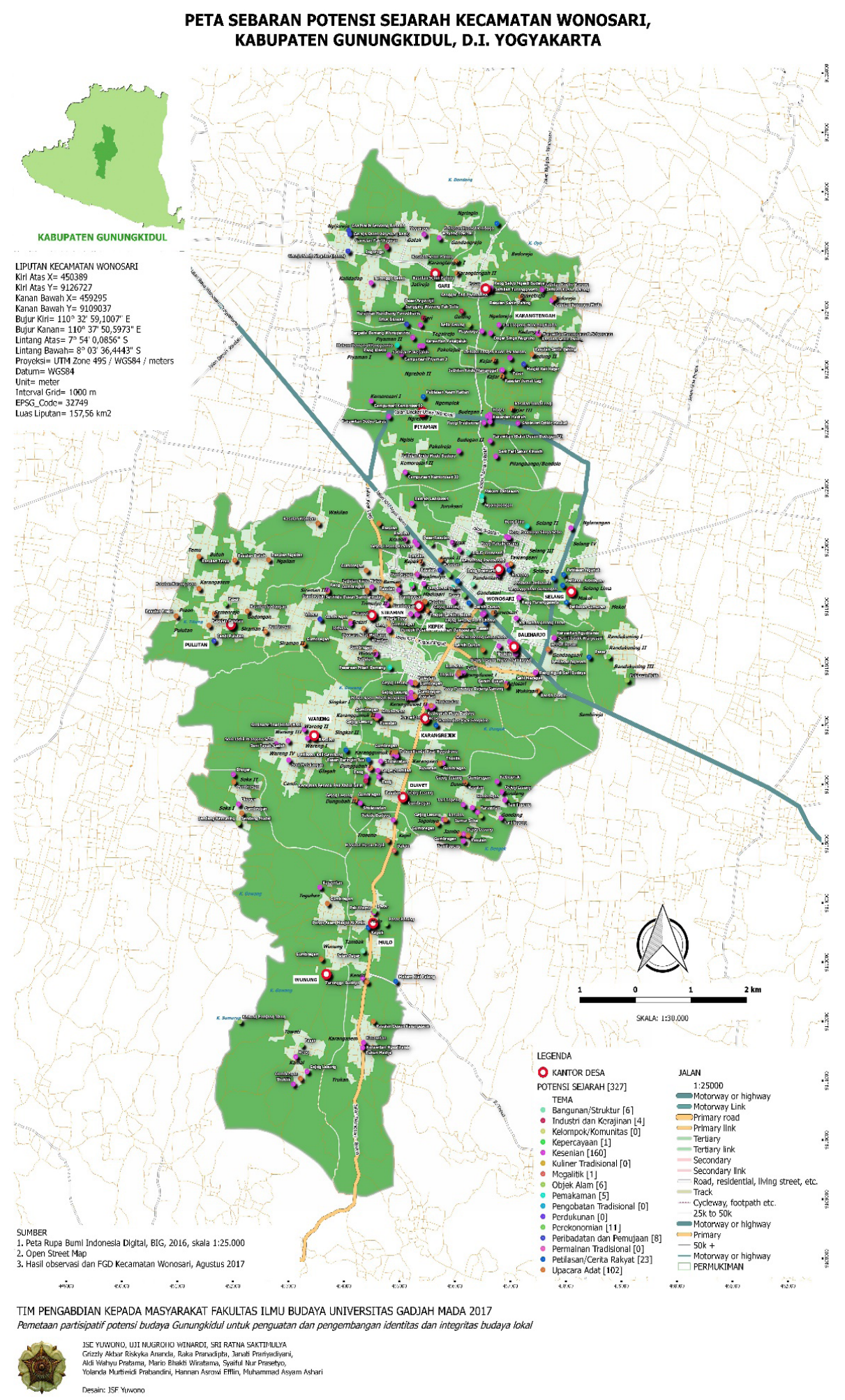

Peta 2. Contoh pemaparan sebaran tema sejarah di wilayah Kecamatan Wonosari (Layout cetak: A1) 


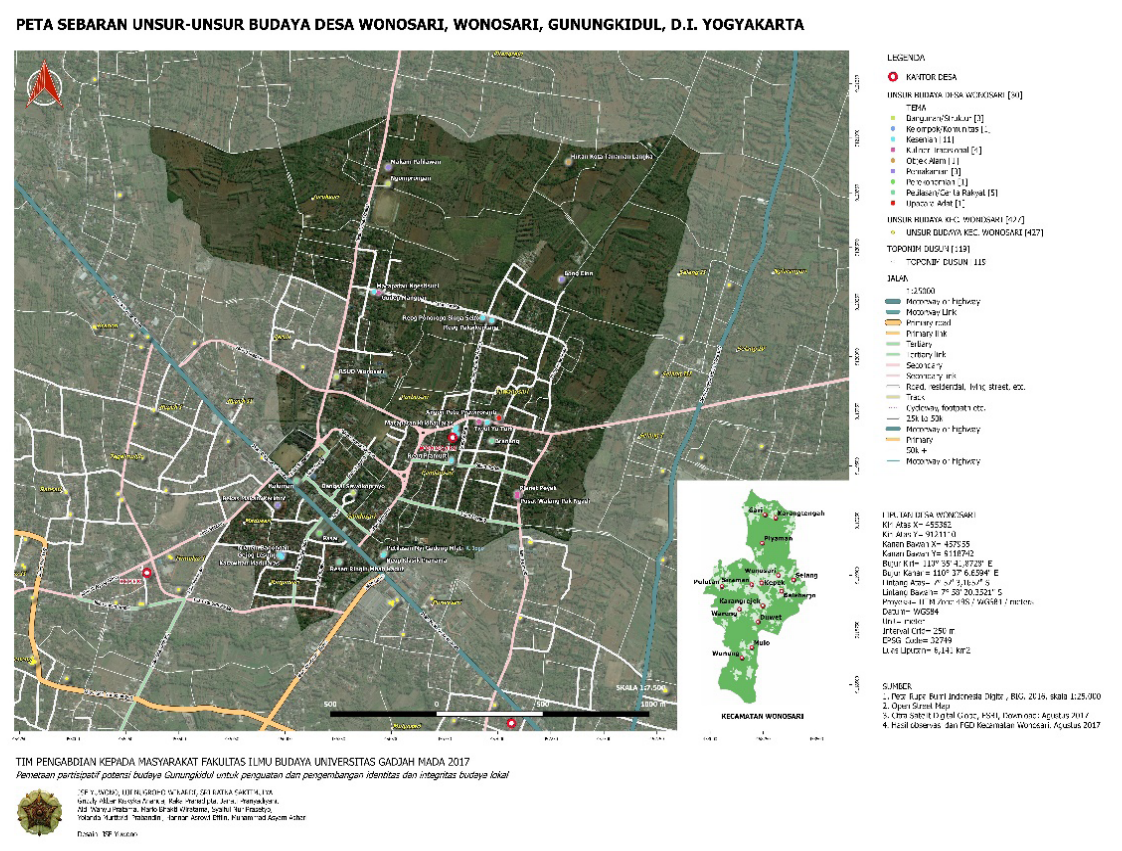

Peta 3. Contoh pemaparan sebaran seluruh tema budaya di Desa Wonosari (Layout cetak A1)

\section{Penutup}

Peta dan basisdata budaya yang merupakan hasil pelibatan masyarakat, dalam skala tertentu telah dapat dimanfaatkan. Secara garis besar hasil PPM ini dapat memfasilitasi masyarakat terutama melalui institusi pemerintahnya paling tidak untuk dua hal, yakni:

- Membangun kesadaran akan potensi budaya yang sangat beragam, masing-masing desa memiliki kekayaan yang berbeda-beda.

- Membantu pemegang kebijakan untuk mendesain kegiatan dan memformulasikan program yang sesuai dengan potensi yang dimiliki masing-masing desa sehingga akan didapatkan hasil yang optimal.

Dalam waktu yang sangat singkat setelah berlangsungnya kegiatan ini - peta dan basisdata potensi budaya Kecamatan Wonosari telah termanfaatkan, contohnya antara lain:

- Sebagai salah satu basis untuk pengajuan status desa budaya bagi desa Wonosari (2017-18) dan direncanakan pula untuk Desa Karangrejek pada tahun berikutnya. Kepentingan yang sama juga direncanakan oleh Desa Mulo.

- Sebagai acuan dalam pengembangan desa untuk disinergikan dengan agenda pembangunan pemerintah, terutama pada tingkat kabupaten, dengan memanfaatkan potensi budaya yang ada. Salah satu contohnya adalah Desa Wunung yang secara geografis berada pada posisi yang tidak begitu strategis, ternyata memiliki potensi alam dan pariwisata yang tinggi dengan adanya sejumlah luweng yang memiliki 
debit air yang besar dan tidak pernah kering. Saat ini, pemerintah Desa Wunung sedang merancang pengembangan potensi luweng sebagai objek wisata yang akan disinergikan dengan program pembangunan pemerintah yang terkait dengan pemanfaatan sumber air.

- Sebagai dasar bagi pemerintah kecamatan maupun kabupaten untuk meramu kebijakan yang lebih tepat sasaran. Salah satu persoalan, sebagai contoh kasus, yang kerap dijumpai adalah distribusi bantuan, semisal gemelan. Desa Mulo yang memiliki banyak potensi namun miskin sarana belum pernah menerima bantuan, sedangkan desa lain yang bahkan tidak memiliki kelompok pengrawit justru memperoleh bantuan. Adanya peta potensi budaya semacam ini dapat digunakan untuk mendistribusikan bantuan secara tepat guna.

Di sisi lain, harus diakui bahwa pemetaan digital dan GIS merupakan teknologi yang belum diuji kemanfaatannya di FIB UGM. Melalui kegiatan ini, pengaplikasian GIS dalam ranah humaniora diharapkan semakin marak. Mahasiswa dan dosen FIB UGM memperoleh sumber data yang terintegrasi dan komprehensif, yang dapat meningkatkan kualitas pelaksanaan Tri Dharma Perguruan Tinggi, tanpa harus terkotak-kotak di dalam masing-masing prodi.

\section{Daftar Bacaan}

Brimicombe, Allan. 2010. GIS, Evironmental Modeling and Engineering, 2nd edition, Taylor \& Francis Group, New York.

Hidayat, Rahmat, Wisnu Adhi, Dianto Bachriadi (ed). 2005. Seri Panduan Pemetaan PartisipatifNomor 5-Jenis-jenis Peta dan Fungsi, Bandung: Garis Pergerakan untuk Jaringan Kerja Pemetaan Partisipatif (JKPP)

Leung, Yee. 2010. Knowledge Discovery in Spatial Data, Springer-Verlag Berlin Heidelberg. Yuwono, JSE. 2015. "National Mapping System of the Archaeological and Historical Sites in Indonesia: A Proposed Model of Spatial Data Integration", The Third Conference: GIS-based Global History from Asian Perspectives, $4^{\text {th }}$ and $7^{\text {th }}$ June, 2015, Graduate School of Humanities and Sociology, Faculty of Letters, The University of Tokyo. Yuwono, JSE, Uji Nugroho Winardi, Sri Ratna Saktimulya, 2017. "Pemetaan Partisipatif Potensi Budaya Gunungkidul untuk Penguatan dan Pengembangan Identitas dan Integritas Budaya Lokal (Tahap I: Kecamatan Wonosari)”, (Submitted to https:// jurnal.ugm.ac.id/jpkm/author/submission/31082, 7 Desember 2017).

\section{Catatan Khusus:}

Kegiatan ini terlaksana berkat sinergi antar prodi di Fakultas Ilmu Budaya UGM melalui keterlibatan mahasiswa dengan latar belakang keilmuan yang berbeda-beda, baik sebagai operator maupun anggota tim. Operator terdiri dari 3 orang: 1) Grizzly Akbar Riskyka Ananda / Arkeologi, 2) Raka Pranadipta / Antropologi, 3) Janati Prariyadiyani / Arkeologi; Anggota terdiri dari 6 orang: 1) Aldi Wahyu Pratama / Arkeologi, 2) Mario Bhakti Wiratama / Antropologi, 3) Syaiful Nur Prasetyo / Sejarah, 4) Yolanda Murtiwidi Prabandini / Pariwisata, 5) Hannan Asrowi Efflin / Sastra Jawa, 6) Muhammad Asyam Ashari / Sastra Indonesia. 